\title{
GNA13 Gene
}

National Cancer Institute

\section{Source}

National Cancer Institute. GNA13 Gene. NCI Thesaurus. Code C115328.

This gene plays a role in heterotrimeric G protein signaling. 